\title{
SPATIO-TEMPORAL EVOLUTIONARY DYNAMICS IN NATURAL BUTTERFLY POPULATIONS (2012 FIELD SEASON)
}

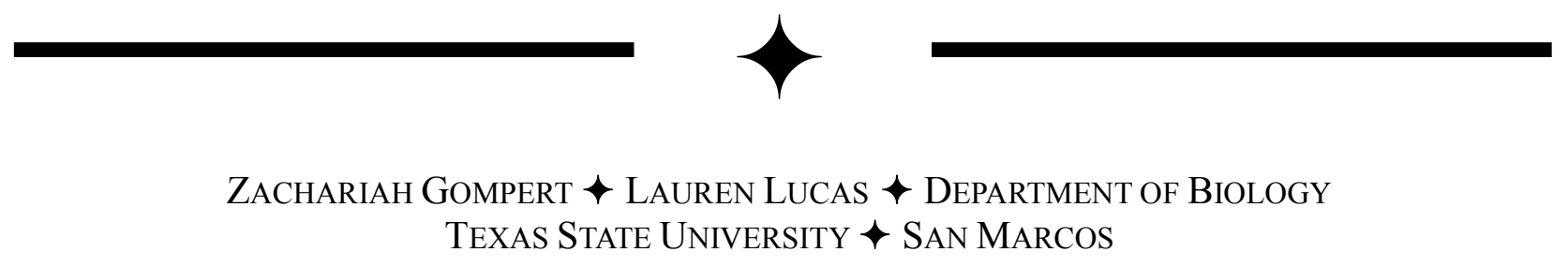

\section{$\uparrow \quad$ INTRODUCTION}

The study of evolution in natural populations has advanced our understanding of the origin and maintenance of biological diversity. For example, long term studies of wild populations indicate that natural selection can cause rapid and dramatic changes in traits, but that in some cases these evolutionary changes are quickly reversed when periodic variation in weather patterns or the biotic environment cause the optimal trait value to change (e.g., Reznick et al. 1997; Grant and Grant 2002). In fact, spatial and temporal variation in the strength and nature of natural selection could explain the high levels of genetic variation found in many natural populations (Gillespie 1994; Siepielski et al. 2009). Long term studies of evolution in the wild could also be informative for biodiversity conservation and resource management, because, for example, data on short term evolutionary responses to annual fluctuations in temperature or rainfall could be used to predict longer term evolution in response to directional climate change. Most previous research on evolution in the wild has considered one or a few observable traits or genes (Kapan 2001; Grant and Grant 2002; Barrett et al. 2008). We believe that more general conclusions regarding the rate and causes of evolutionary change in the wild and selection's contribution to the maintenance of genetic variation could be obtained by studying genome-wide molecular evolution in a suite of natural populations. Thus, we have begun a long term study of genomewide molecular evolution in a series of natural butterfly populations in the Greater Yellowstone Area (GYA). This study will allow us to quantify the contribution of environment-dependent natural selection to evolution in these butterfly populations and determine whether selection consistently favors the same alleles across space and through time.
The focal species, Lycaeides idas, is one of five nominal species of Lycaeides butterflies that occur in North America (Figure 1; Nabokov 1949; Guppy and Shepard, 2001; Gompert et al. 2006). These species are descended from one or more Eurasian ancestors that colonized North America about 2.4 million year ago (Vila et al. 2011). Lycaeides idas 73eticulate with a second species, L. 73eticul, in the GYA (Gompert et al. 2010, 2012). Lycaeides idas is a 73eticulat species that is found in Alaska, Canada, and the central and norther Rocky Mountains of the contiguous USA (Scott 1986). Lycaeides idas is univoltine and adults generally fly from mid-July to early August. In the GYA L. idas populations often occupy mesic forest and montane habitat at elevations ranging from 2000$3500 \mathrm{~m}$ above sea level. Most populations of $L$. idas in the GYA feed on Astragalus miser as larvae, but some populations feed on other native legumes (most notably, other species of Astragalus and Lupinus; Gompert et al. 2010). We selected L. idas as the focal species for this study because of our experience with this species, extensive data on the location and natural history of $L$. idas populations, the availability of genomic resources for this species, and several key aspects of this species's natural history (e.g., L. idas have non-overlapping generations with one generation per year, well-defined populations, and modest genome sizes, and L. idas are found in various habitats that might experience different environmentdependent selection pressures).

The specific goals of this study are to: 1) quantify genetic variation and molecular evolution in L. idas and their relationship with population size and environmental variation across space (i.e., different populations) and through time (i.e., from generation to generation) and 2) test the hypothesis that the nature 
and strength of environment-dependent selection varies among populations and over generations and that this variation is sufficiently large to contribute to the maintenance of genetic variation in L. idas. This report documents the results from the first year of this study (2012), during which time we began collecting L. idas for DNA sequencing and conducted a pilot project to quantify population sizes (population size is an important parameter for our evolutionary models).

Figure 1. Photograph of a L. idas butterfly perched on an Aster.

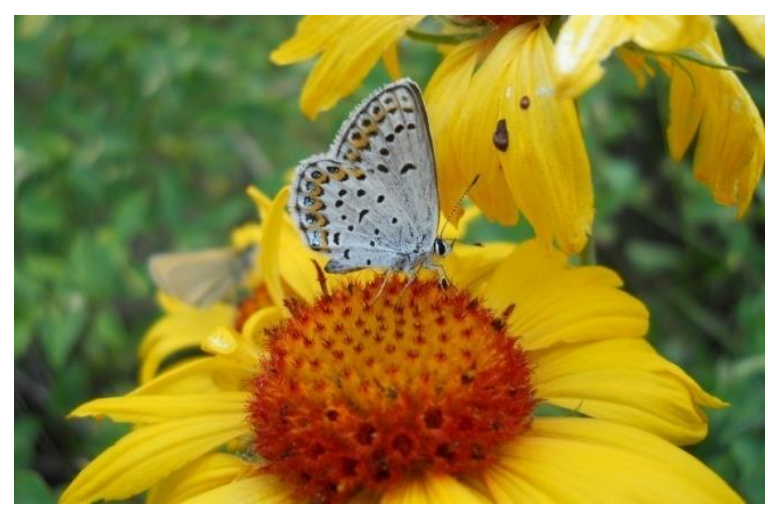

\section{MethodS}

We began this long-term study in July of 2012. Consequently, this report covers the first year of the study. We collected 379 adult Lycaeides idas butterflies from 11 locations (Table 1). We are storing these whole adult butterflies for DNA extraction and sequencing at $-80^{\circ} \mathrm{C}$. In addition, we conducted a pilot study to evaluate a distance sampling protocol to estimate adult population densities and sizes in L. idas. Distance sampling involves counting individuals and recording their distance from a transect line or point (Buckland et al., 2001). This distance information is used to estimate a detection function that accounts for imperfect detection away from the transect line. We included four sites in the pilot study: Bull Creek (BCR), Blacktail Butte (BTB), Bunsen Peak (BNP), and Garnet Peak (GNP). We haphazardly designated linear transects at each of the four sites (Figures 2 and 3; BCR: 6 transects, total length $=487.7$ meters $[\mathrm{m}]$; BTB: 7 transects, total length $=579.1 \mathrm{~m}$; BNP: 6 transects, total length $=502.9 \mathrm{~m}$; GNP: 5 transects, total length $=411.5 \mathrm{~m}$ ).

Two trained observers slowly walked along each transect (about one pace per second) and measured and recorded the distance of each observed L. idas perpendicular to the transect line. We also observed and recorded the sex of each butterfly and the presence or absence of the larval host plant
(Astragalus miser) near the transect line. We conducted these population surveys from July $18^{\text {th }}$ until July $30^{\text {th }}$, and we only performed transect counts between 10:00 am and 2:00 pm under sunny or partly sunny skies.

Table 1. Population identification, locations, and number of adults $(\mathrm{m}=$ male, $\mathrm{f}=$ female $)$ collected at each site for DNA sequencing. Sites within National Park boundaries are noted $($ GTNP $=$ Grand Teton National Park, YNP $=$ Yellowstone National Park).

\begin{tabular}{|c|c|c|c|}
\hline Population & Latitude & Longitude & $\begin{array}{l}\text { Sample } \\
\text { size }\end{array}$ \\
\hline $\begin{array}{l}\text { Big } \\
\text { Ice Cave }\end{array}$ & $45^{\circ} 10^{\prime} \mathrm{N}$ & $108^{\circ} 24^{\prime} \mathrm{W}$ & $6 \mathrm{~m}, 12 \mathrm{f}$ \\
\hline $\begin{array}{l}\text { Blacktail } \\
\text { (GTNP) }\end{array}$ & $43^{\circ} 38^{\prime} \mathrm{N}$ & $110^{\circ} 41^{\prime} \mathrm{W}$ & $25 \mathrm{~m}, 25 \mathrm{f}$ \\
\hline Bull Creek & $43^{\circ} 18^{\prime} \mathrm{N}$ & $110^{\circ} 33^{\prime} \mathrm{W}$ & $30 \mathrm{~m}, 28 \mathrm{f}$ \\
\hline Bunsen Peak (YNP) & $44^{\circ} 56^{\prime} \mathrm{N}$ & $110^{\circ} 43^{\prime} \mathrm{W}$ & $25 \mathrm{~m}, 25 \mathrm{f}$ \\
\hline Garnet Peak & $45^{\circ} 26^{\prime} \mathrm{N}$ & $111^{\circ} 13^{\prime} \mathrm{W}$ & $25 \mathrm{~m}, 25 \mathrm{f}$ \\
\hline Grassy Lake Road & $44^{\circ} 08^{\prime} \mathrm{N}$ & $110^{\circ} 47^{\prime} \mathrm{W}$ & $16 \mathrm{~m}, 6 \mathrm{f}$ \\
\hline Hunt Mountain & $44^{\circ} 45^{\prime} \mathrm{N}$ & $107^{\circ} 45^{\prime} \mathrm{W}$ & $13 \mathrm{~m}, 21 \mathrm{f}$ \\
\hline $\begin{array}{l}\text { Natural } \\
\text { (YNP) }\end{array}$ & $44^{\circ} 32^{\prime} \mathrm{N}$ & $110^{\circ} 27^{\prime} \mathrm{W}$ & $7 \mathrm{~m}, 10 \mathrm{f}$ \\
\hline $\begin{array}{l}\text { Rendezvous } \\
\text { Mountain (GTNP) }\end{array}$ & $43^{\circ} 36^{\prime} \mathrm{N}$ & $110^{\circ} 53^{\prime} \mathrm{W}$ & $15 \mathrm{~m}, 15 \mathrm{f}$ \\
\hline Riddle Lake (YNP) & $44^{\circ} 22^{\prime} \mathrm{N}$ & $110^{\circ} 33^{\prime} \mathrm{W}$ & $15 \mathrm{~m}, 15 \mathrm{f}$ \\
\hline Tibbs Butte & $44^{\circ} 57^{\prime} \mathrm{N}$ & $109^{\circ} 27^{\prime} \mathrm{W}$ & $16 \mathrm{~m}, 4 \mathrm{f}$ \\
\hline
\end{tabular}

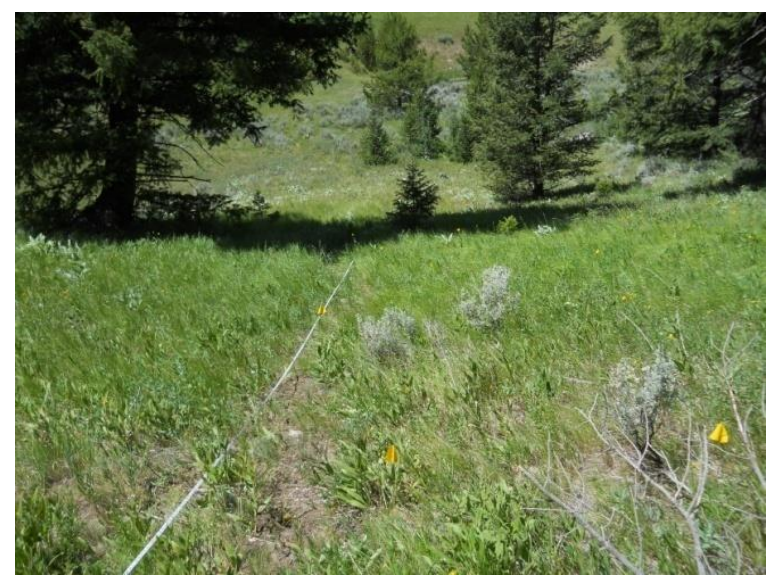

Figure 2. Photograph of a transect for distance sampling. The white line is the transect line and yellow flags indicate the location of observed L. idas butterflies.

We estimated population densities (adult butterflies per square kilometer) using the distsamp function in the unmarked $R$ package. We binned the 
detection distances of butterflies into 1 meter bins prior to analysis (e.g., 0 to $1 \mathrm{~m}, 1$ to $2 \mathrm{~m}$, etc.). We used a half-normal detection function and estimated the detection function and density model parameters using maximum likelihood (Royle 2004). This model assumes the latent transect-level abundance distribution is Poisson and that the detection processes is multinomial with a different detection probability for each distance class or bin.

\section{$\uparrow \quad$ RESULTS}

We observed and recorded distances for 121 butterflies across the four sites and 24 linear transects. Based on these observations our estimates of adult $L$. idas population density were: 0.0151 butterflies per square meter (standard error [se] 0.00333) at BCR, 0.0166 butterflies per square meter (se 0.00315 ) at BTB, 0.0105 butterflies per square meter (se 0.00256 ) at BNP, and 0.00292 butterflies per square meter (se 0.000843 ) at GNP. We converted these density estimates to estimates of peak census population size based on rough estimates of each population's range (we identified suitable habitat from ground surveys and satellite images). Peak population size estimates were 1340 butterflies (BCR), 2380 butterflies (BTB), 720 butterflies

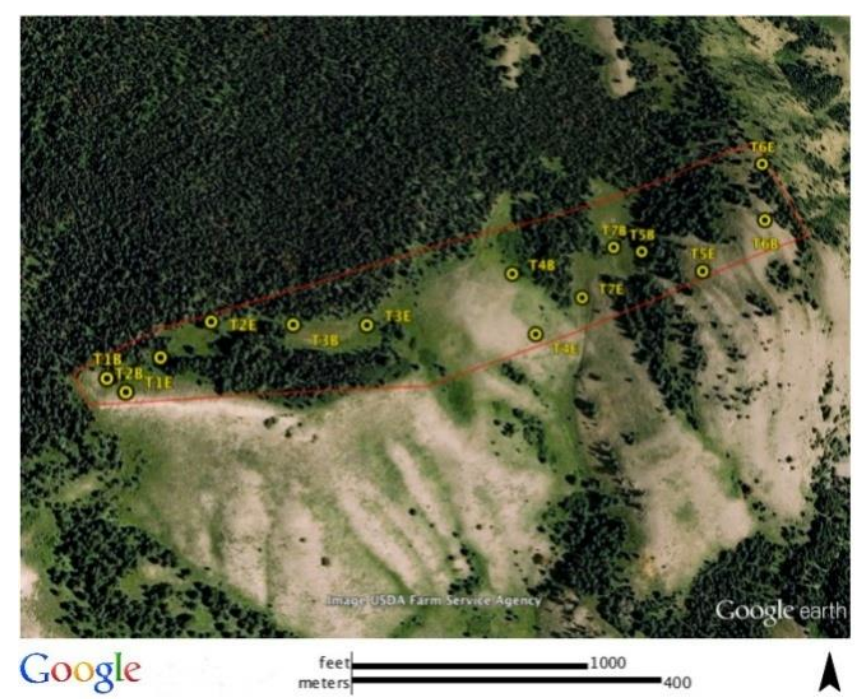

Figure 3. This google earth image shows the approximates boundary of the L. idas BTB population (red polygon) and the start and end points of transects (yellow circles; transects are numbered $\mathrm{T} 1$ to $\mathrm{T} 7$ and the letters B and $\mathrm{E}$ denote the start and end points, respectively).

(BNP), and 206 butterflies (GNP). Because adult $L$. idas eclose (i.e., emerge following pupation) over a period of several weeks, these peak population size estimates are underestimates of the total adult population size at each site (perhaps by a factor of about three or four times given a one month flight season and a rough estimate of adult survival time in the wild of seven to ten days).

\section{$\uparrow \quad$ DISCUSSION}

Because we have just begun this long term study and we have not yet sequenced the DNA from the sampled butterflies, we cannot yet make any conclusions about the rates or causes of molecular evolution in these study populations. But we have already learned a few things from the pilot distance sampling surveys and analyses. These initial analyses indicate that the four focal sites sustain adult $L$. idas populations of hundreds to thousands of individuals. These are the first population size estimates for this butterfly species. Based on these moderate population size estimates we predict that both genetic drift and selection are important drivers of evolution in this system (Lynch, 2007). The population density standard errors were neither particularly small or large (they were about one-quarter the size of the density estimates). Thus, whereas these density estimates provide valuable baseline data, this study would benefit from more precise population size estimates which could readily be obtained by increasing the number of transects we survey at each site. We will continue this study during the 2013 summer field season. During this and subsequent field seasons we will increase the number of sites that we visit for DNA samples and population density surveys (we hope to visit 10 to 12 sites each year). We will also begin collecting weather and habitat data that will be useful for fitting causal models of molecular evolution. We plan to begin DNA sequencing of the collected L. idas after one or two additional field seasons.

\section{LITERATURE CITED}

Barrett RDH, Rogers SM, Schluter D. 2008. Natural selection on a major armor gene in threespine stickleback. Science 322:255-257.

Buckland ST, Anderson DR, Burnham KP, Laake JL, Borchers DL, Thomas L. 2001. Introduction to distance sampling: estimating abundance of biological populations. Oxford University Press, USA.

Gillespie JH. 1994. The Causes of Molecular Evolution. Oxford University Press, USA. 
Gompert Z, Fordyce JA, Forister ML, Shapiro AM, Nice CC. 2006. Homoploid hybrid speciation in an extreme habitat. Science 314:19231925.

Gompert Z, Lucas LK, Fordyce JA, Forister ML, Nice CC. 2010. Secondary contact between Lycaeides idas and L. 76eticul in the Rocky Mountains: extensive introgression and a patchy hybrid zone. Molecular Ecology 19:3171-3192.

Gompert Z, Lucas LK, Nice CC, Fordyce JA, Forister ML. 2012. Genomic regions with a history of divergent selection affect fitness of hybrids between two butterfly species. Evolution 66:2167-2181.

Grant PR, Grant BR. 2002. Unpredictable evolution in a 30-year study of Darwin's finches. Science 296:707-711.

Guppy C, Shepard J. 2001. Butterflies of British Columbia. UBC Press.

Kapan D. 2001. Three-butterfly system provides a field test of müllerian mimicry. Nature 409:338-340.

Lynch M. 2007. The origins of genome architecture. Sinauer Associates, Sunderland MA.
Nabokov V. 1949. The nearartic members of Lycaeides Hübner (Lycaenidae, Lepidoptera). Bulletin of the Museum of Comparative Zoology 101:479541.

Reznick DN, Shaw FH, Rodd FH, Shaw RG. 1997. Evaluation of the rate of evolution in natural populations of guppies (Poecilia 76eticulate). Science 275:1934-1937.

Royle JA, Dawson DK, Bates S. 2004. Modeling abundance effects in distance sampling. Ecology 85:1591-1597.

Scott J. 1986. The Butterflies of North America: A Natural History and Field Guide. Stanford University Press

Siepielski AM, DiBattista JD, Carlson SM. 2009. It's about time: the temporal dynamics of phenotypic selection in the wild. Ecology Letters 12:1261-1276.

Vila R, Bell CD, Macniven R, et al. 2011. Phylogeny and palaeoecology of Polyommatus blue butterflies show Beringia was a climateregulated gateway to the New World. Proceedings of the Royal Society B: Biological Sciences. 278:2737-2744. 